\title{
A NEW METHOD OF DETERMINING FACIAL SIZE FOR THREE-DIMENSIONAL PHOTOGRAMMETRY QUANTIFICATION
}

\author{
NOVA METODA DOLOČANJA VELIKOSTI OBRAZA V \\ TRIDIMENZIONALNI FOTOGRAMETRIJI
}

\author{
Miha Verdenik $^{1 *}$, Nataša Ihan Hren ${ }^{1}$, Žiga Kadivnik ${ }^{2}$, Igor Drstvenšek ${ }^{3}$ \\ ${ }^{1}$ Department of Oral and Maxillofacial Surgery, University Medical Center Ljubljana, Zaloška 2, 1000 Ljubljana, Slovenia \\ ${ }^{2}$ Ortotip LLC, Obrtna ulica 40, 9000 Murska Sobota, Slovenia \\ ${ }^{3}$ Faculty of Mechanical Engineering, University of Maribor, Smetanova ulica 17, 2000 Maribor, Slovenia
}

Prejem rokopisa - received: 2020-06-09; sprejem za objavo - accepted for publication: 2020-07-24

doi:10.17222/mit.2020.113

\begin{abstract}
Contemporary craniofacial surgery includes the pre- and post-operative optical 3D scanning of faces as a method for diagnosing and verifying the achieved results. The influence of head size in 3D scans must be excluded in order to accurately and uniformly compare different three-dimensional facial shapes in craniofacial surgery. Regarding this purpose, different head-size parameters must be measured to obtain the scaling factor. A special device, a so-called head ring, has been produced as a structure that can be fixed to a person's head. Among defined points, different linear distances (head width, length and height) and volumetric parameters (lower and upper head volumes) were calculated and compared to body-size measurements. Measurements were performed on 3D scans of the heads of 26 healthy adults with normocclusion (12 men and 14 women) taken using the head ring set. Body mass index (BMI) statistically significantly correlates with the lower and whole-head volume in men, while in women more precisely with the upper-head volume. BMI in men does not correlate with any linear distance, while in women it is closely connected to the facial width. In men the head width and lower head volume are the main contributors to head size, while in women the crown-to-chin length and upper volume determine the size of the head. A conclusion can be made that the correlation between the head volume, the BMI and the linear head parameters exists and is gender dependent.

Keywords: 3D, facial, size, photogrammetry
\end{abstract}

$\mathrm{Na}$ področju karniofacialne kirurgije so vedno bolj uveljavljene 3D-metode, med njimi tudi neinvazivni površinski posnetki glave in obraza. Za natančno primerjavo 3D-posnetkov različnih obrazov med seboj, je potrebno izklljučiti vpliv velikosti glave in obraza. Za namen bolj objektivne registracije, je bil izdelan poseben pripomoček, ki smo ga poimenovali naglavni obroč. Z njegovo uporabo smo pridobili dodatne podatke, kot so: razdalja med ušesi, razdalja med najvišjo točko glave in brado, razdalja med navideznim središčem in bazo nosu ter s pomočjo markerjev izmerjeni volumen spodnje in zgornje piramide ter volumen elipsoida, ki ga markerji opišejo. Dodatno je možno, kot parameter določanja velikosti obraza, uporabiti tudi indeks glave (kot analog obraznemu indeksu) izračunan kot razmerje med obrazno dolžino in širino. Meritve so bile izvedene na 26 zdravih preiskovancih brez skeletnih in zobnih nepravilnosti (12 moških in 14 ženskah). ITM (indeks telesne mase) je značilno koreliral Z volumnom spodnje obrazne piramide in celotnim volumnom pri moških preiskovancih, pri ženskah pa z volumnom zgornje piramide. ITM pri moških ni imel značilne povezave $z$ opazovanimi linearnimi razdaljami, pri ženskah pa smo našli povezavo $z$ razdaljo med ušesi. Pri moških smo ugotovili, da k velikosti glave najbolj prispevata razdalja med ušesi in volumen spodnje piramide, pri ženskah pa razdalja med najvišjo točko glave in brado ter volumen zgornje piramide. Ugotovljene so bile značilne povezave med ITM, spolom in nekaterimi obraznimi parametri, ki smo jih določili s pomočjo naglavnega obroča.

Ključne besede: 3D, obraz, velikost, fotogrametrija

\section{INTRODUCTION AND BACKGROUND}

The tree-dimensional (3D) analysis of facial soft tissues is an important diagnostic and research tool in craniofacial surgery, ${ }^{1}$ but it could also be useful for detecting changes during growth and treatment. There are two major problems in a comparison of two faces. First, we have to distinguish between size and shape. ${ }^{2}$ If we want to compare just the facial shapes, we must scale the faces to the same size, which is hard to define. The centroid size from general procrusted analysis is mostly used,,$^{2-4}$ with some disadvantages, as it used for a limited number of points for size determination, whilst 3D surface scanning provides us with an enormous data set.

*Corresponding author's e-mail:

miha.verdenik@gmail.com (Miha Verdenik)
The second problem is how to orient two facial scans within a working space to achieve their optimal registration. The cranial base is often used for super-impositioning when comparing lateral cephalograms ${ }^{5}$ as well as different CT scans ${ }^{6}$ because it shows minimal changes after childhood and it is a good reference point for comparing two different faces. But facial scans represent only soft-tissue contours, so we are unable to compare them based on skeletal structures as a cranial base. There are other methods available, i.e., general procrusted analysis, iterative closest point (best-fit) ${ }^{5}$ regional best-fit ${ }^{6,7}$ mid-endocanthion registration, ${ }^{3}$ but none of them is perfect. We have used iterative closest-point registration in our 3D description of class-III faces. ${ }^{8}$ We have also determined the average Slovenian facial shell ${ }^{9}$ because of its ethically bonded facial characteristics. ${ }^{10}$ The presented research was triggered by the discrepancies when 


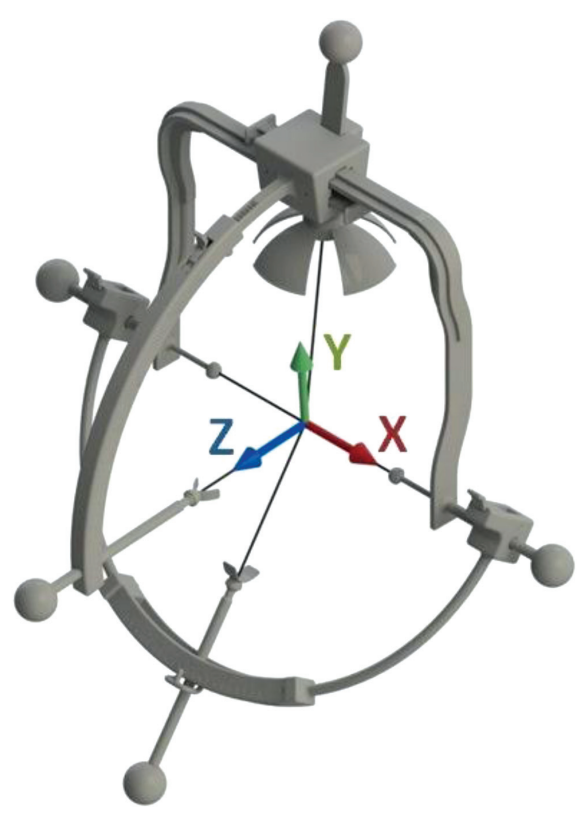

Figure 1: Innovated head-ring with a schematic view of the coordinate system

calculating the differences between face shapes before and after orthognathic surgery. The results gathered in the described way were unsatisfactory because they did not reflect the actual displacements of the facial structures for several reasons, among which changes in the body mass index and differences in body sizes between the averaged and the actual face seemed to be the main reasons.

In order to avoid these generalisations induced by the best-fit method, two obvious possibilities are available. One is to scan the whole head's volume, which is a technically impossible process because the hairy surfaces cannot be scanned without special preparation. The second is to find a way of uniformly defining the orientation of a facial scan by introducing special markers that do not change for subsequent scans and that do not depend on personal particularities.
This study was aimed at finding a correlation for different facial, head, and body-size parameters. An innovative head ring was used to obtain additional data that are usually excluded during 3D surface facial scanning. The aim of our study was to find the best parameter that will be used as a descriptor of the head volume. This parameter can then be used as a coefficient to scale the faces of different sizes for shape analysis.

\section{METHODS}

A special device called a head-ring has been produced that consists of a structure that can be fixed to a person's head with spherical markers attached to the holding structure in such a way that enables their movements to touch the characteristic points on the head, while still preserving a position relative to the origin of the whole structure, e.g., the person's head volume (Figure 1). Five spherical markers point to five characteristic points of a human head: both acoustic ducts, the crown of the head (the highest point of the head during a natural head position), the nasal base, and the chin. Since these points are hard to detect while scanning, the markers have been designed in such a way that enables their exact scanning in the head-space, while simultaneously marking these five points exactly on the head's surface. This has been achieved by designing a marker that consists of a scanning sphere, a "skin-piece" that touches the head's surface and a pole that connects the spherical marker to the skin piece. In this way the marker not only represents a point on the face's surface, but also a vector that points to the origin of the head's volume.

To prove the measurement principles and usability of the head-ring, its prototype was produced from polyamide (PA12) using the selective laser sintering process. The first trials pointed out some awkward solutions in the design (fixation of markers, positioning the ring onto the crown of the head, etc.), but they did not influence the facial scanning. A pilot study was performed that included 27 young adults (14 female and 13 male, average age $25 \pm 2$ and $26 \pm 3$ years). They were all healthy
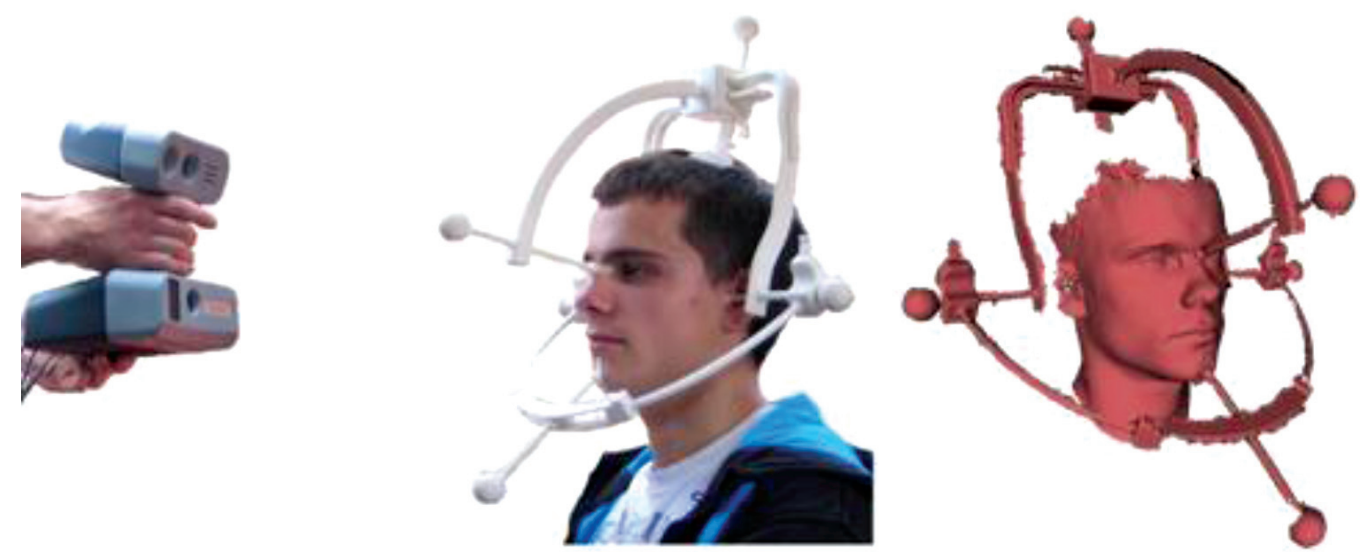

Figure 2: Photos and 3D facial scan with the innovated head ring set on 

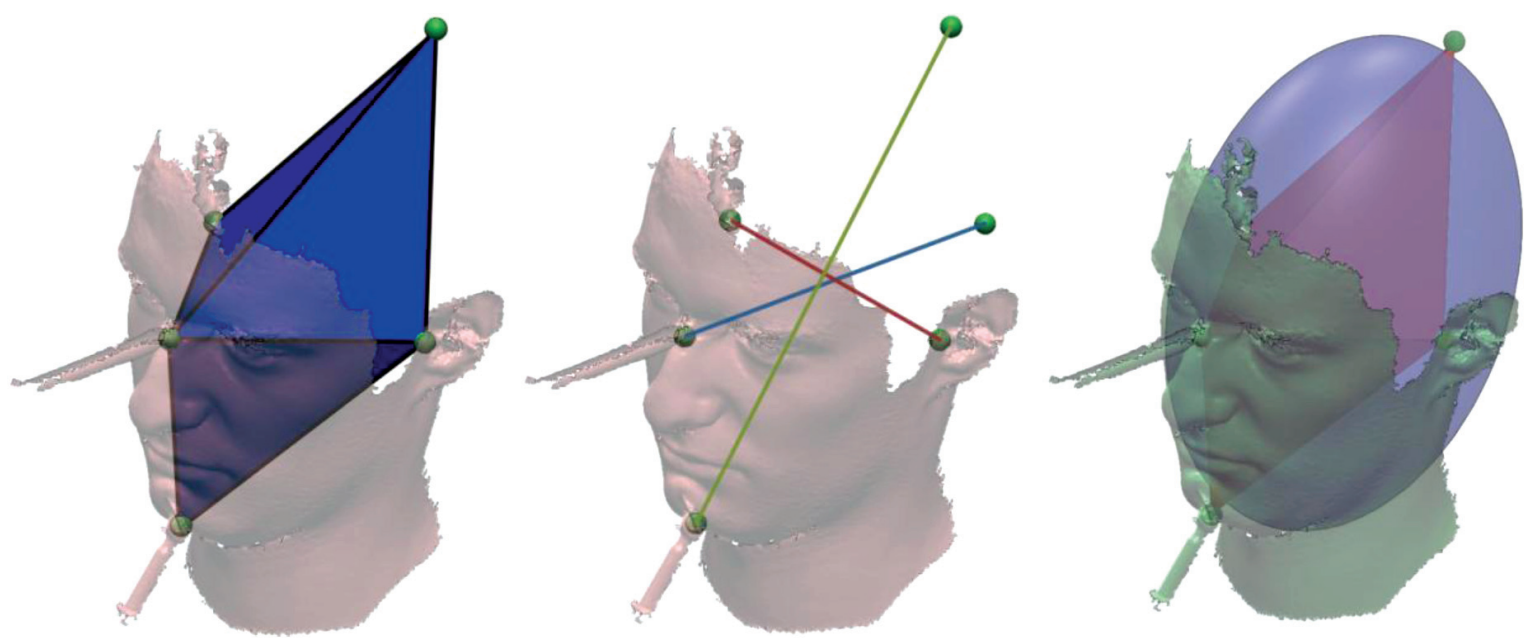

Figure 3: Measured parameters (lower, upper head volume, width, length, facial depth, ellipsoid) shown on the 3D facial scan

with normocclusion, without any dentofacial deformities. We obtained a signed, informed consent.

Each participant's weight and height were measured and 3D facial scans were (Figure 2) obtained using an Artec 3D MH scanner that uses the flying-triangulation method. ${ }^{11}$ The scans were taken in a relaxed environment, with the subjects sitting on an ergonomic chair in a straightened posture, with the gaze fixed on a determined point in the distance, so as to exclude the subject's self-awareness of the facial muscles and reconstruct a realistic physiological rest position. The volunteers were asked to refrain from any movements - if possible, as well from blinking - for the period of the scanning procedure (about 15-20 s). During the scanning they wore the head-ring on the head and 3D facial scans were later processed in the Artec Studio software. Furthermore, the distances were measured between the ears, between the crown of the head and the chin, and between the head volume's origin and nasal base. The head-width as the distance between the ears, length as distance between the crown of the head and the chin and the facial depth as distance between the centre and the nose. The volumes of the upper and lower pyramids, as well as the whole head's and ellipsoid volumes (Figure 3), were calculated using these data. Additionally, the head index, was calculated from the distance between the crown of the head to the chin and, both ears distance relationships.

Each of the 11 obtained parameters (Table 1) describes the facial size in its own way. In the first part the similarity and correlation had to be checked among them. The observed subjects were arranged from the smallest to tallest according to their body heights followed by graphical visualisations of how other parameters follow (Figure 4). Further on the Pearson correlation

Table 1: Obtained parameter descriptions

\begin{tabular}{|c|c|c|c|}
\hline Parameter & Definition - equation & Unit & Description \\
\hline Height & Body height & $\mathrm{cm}$ & \\
\hline Weight & Body weight & $\mathrm{kg}$ & \\
\hline BMI & Weight/Height ${ }^{2}$ & $\mathrm{~kg} / \mathrm{m}^{2}$ & \\
\hline Distance between ears (b) & $\begin{array}{l}\text { Distance from left to right point, where head ring touches the } \\
\text { external acoustic ducts. }\end{array}$ & $\mathrm{mm}$ & Head width \\
\hline $\begin{array}{l}\text { Distance from crown of } \\
\text { the head to the chin (a) }\end{array}$ & $\begin{array}{l}\text { Distance from the uppermost point on the head in the natural } \\
\text { head position, to the chin. }\end{array}$ & $\mathrm{mm}$ & Head length \\
\hline $\begin{array}{l}\text { Distance from centre to } \\
\text { the nasion }(c)\end{array}$ & $\begin{array}{l}\text { Distance from the centre point, origin of the head volume cre- } \\
\text { ated where vectors from other spherical markers meet, to the } \\
\text { tip of the nose. }\end{array}$ & $\mathrm{mm}$ & Face depth \\
\hline Head-index $(\mathrm{a} / \mathrm{b})$ & $\begin{array}{l}\text { Is an analogue of facial one (the ratio of the facial height to } \\
\text { the zygomatic width) calculated from the distances between } \\
\text { the crown of the head to the chin and both ears. }\end{array}$ & & Head form \\
\hline Upper-volume & $\begin{array}{l}\text { Volume of upper pyramid between the crown of the head, both } \\
\text { ears and the nasion. }\end{array}$ & $\mathrm{cm}^{3}$ & \\
\hline Lower-volume & $\begin{array}{l}\text { Volume of lower pyramid between both ears, nasion, and the } \\
\text { chin. }\end{array}$ & $\mathrm{cm}^{3}$ & \\
\hline Whole-volume & Sum of both volumes & $\mathrm{cm}^{3}$ & Head volume \\
\hline Ellipsoid & $\begin{array}{l}\text { Calculated volume of ellipsoid defined as \#, where } a, b \text {, and } 2 c \\
\text { represent the three axes of the ellipsoid. }\end{array}$ & $\mathrm{cm}^{3}$ & \\
\hline
\end{tabular}




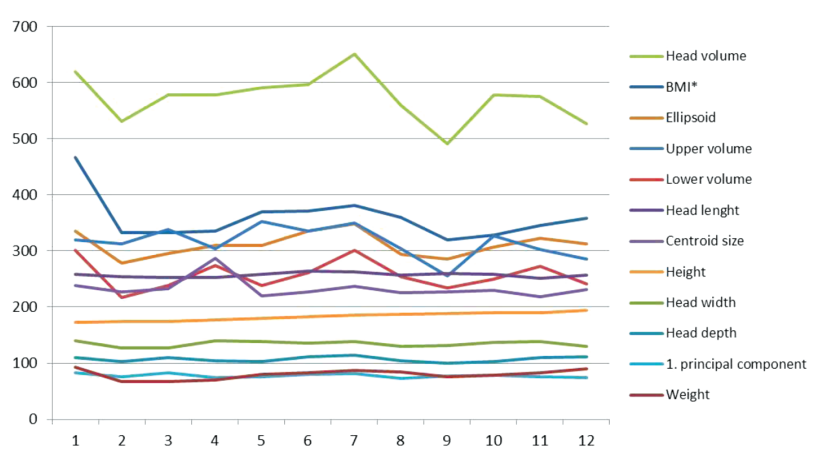

Figure 4: Graphically visualised male parameters' distribution

was used to statistically assess the correlation among these data $(p<0.5)$. It was supposed that the head volume would describe the facial size best; therefore, a linear regression model was made with the head-volume as the dependent value. This model was used to check the impacts of head width, length, facial depth, body weight, and height.

Table 2: Values of all obtained parameters for all the subjects

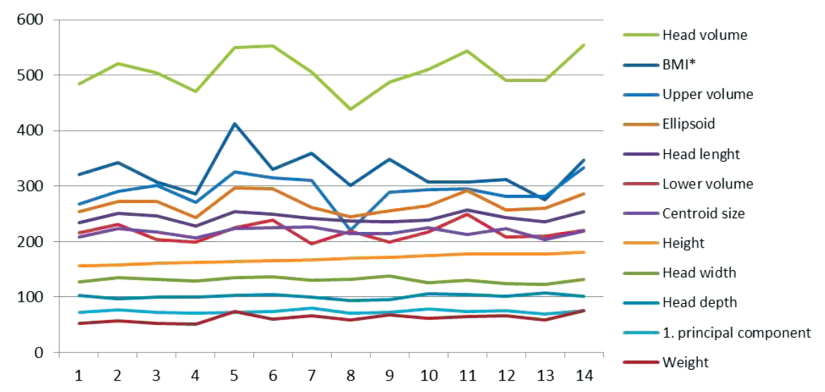

Figure 5: Graphically visualised female parameters' distribution

\section{RESULTS AND DISCUSSION}

In the presented study, the young adults with normocclusion were similar regarding BMI. The average BMI was 22.8 (SD 3.1), which meant that abnormal indexes were excluded. The number of observed participants was small, but enough for statistically relevant results. Both genders were separately observed because of

\begin{tabular}{|c|c|c|c|c|c|c|c|c|c|c|c|c|}
\hline & ID & Height & Weight & BMI & $\begin{array}{l}\text { Dist. } \\
\text { between } \\
\text { ears }\end{array}$ & $\begin{array}{c}\text { Dist. } \\
\text { crown of } \\
\text { the head } \\
\text { chin }\end{array}$ & $\begin{array}{l}\text { Dist. } \\
\text { centre - } \\
\text { nasion }\end{array}$ & $\begin{array}{l}\text { Head- } \\
\text { index }\end{array}$ & $\begin{array}{l}\text { Upper- } \\
\text { volume }\end{array}$ & $\begin{array}{l}\text { Lower- } \\
\text { volume }\end{array}$ & $\begin{array}{l}\text { Whole- } \\
\text { volume }\end{array}$ & Ellipsoid \\
\hline \multirow{15}{*}{ 自 } & 1 & 173 & 93 & 31.1 & 139.5 & 259.1 & 110.8 & 1.86 & 319.1 & 300.8 & 619.9 & 335.6 \\
\hline & 2 & 175 & 68 & 22.2 & 127.7 & 254.5 & 102.5 & 1.99 & 313.4 & 217.5 & 530.8 & 279.2 \\
\hline & 3 & 175 & 68 & 22.2 & 127.0 & 252.9 & 109.9 & 1.99 & 339.1 & 238.3 & 577.4 & 295.7 \\
\hline & 4 & 177 & 70 & 22.3 & 139.6 & 252.7 & 105.0 & 1.81 & 304.0 & 274.5 & 578.5 & 310.2 \\
\hline & 5 & 180 & 100 & 30.9 & 134.6 & 245.0 & 97.8 & 1.82 & 262.5 & 241.6 & 504.0 & 270.2 \\
\hline & 6 & 180 & 80 & 24.7 & 139.3 & 259.1 & 102.5 & 1.86 & 352.4 & 238.1 & 590.6 & 309.8 \\
\hline & 7 & 183 & 83 & 24.8 & 136.0 & 264.0 & 111.7 & 1.94 & 336.0 & 261.0 & 597.0 & 336.0 \\
\hline & 8 & 186 & 88 & 25.4 & 139.0 & 262.2 & 114.2 & 1.89 & 349.2 & 301.1 & 650.3 & 348.6 \\
\hline & 9 & 187 & 84 & 24.0 & 130.2 & 257.6 & 104.8 & 1.98 & 304.7 & 254.9 & 559.5 & 294.4 \\
\hline & 10 & 189 & 76 & 21.3 & 131.6 & 259.8 & 99.6 & 1.97 & 255.7 & 234.7 & 490.4 & 285.1 \\
\hline & 11 & 190 & 79 & 21.9 & 136.9 & 259.0 & 103.4 & 1.89 & 327.7 & 249.8 & 577.5 & 307.1 \\
\hline & 12 & 190 & 83 & 23.0 & 138.5 & 250.8 & 110.7 & 1.81 & 303.1 & 272.7 & 575.8 & 322.3 \\
\hline & 13 & 194 & 90 & 23.9 & 130.2 & 256.5 & 111.6 & 1.97 & 285.5 & 240.8 & 526.3 & 312.4 \\
\hline & & 183 & 82 & 24.4 & 134.6 & 256.4 & 106.5 & 1.91 & 311.7 & 255.8 & 567.5 & 308.2 \\
\hline & $\pm \mathrm{SD}$ & 7 & 10 & 3.0 & 4.7 & 5.1 & 5.2 & 0.07 & 30.5 & 25.4 & 45.2 & 23.4 \\
\hline \multirow{16}{*}{ 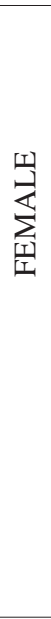 } & 1 & 156 & 52 & 21.4 & 127.1 & 233.8 & 102.0 & 1.84 & 267.6 & 216.1 & 483.7 & 2342.9 \\
\hline & 2 & 158 & 57 & 22.8 & 135.2 & 250.3 & 95.9 & 1.85 & 290.4 & 231.1 & 521.5 & 2931.2 \\
\hline & 3 & 161 & 53 & 20.4 & 131.8 & 246.5 & 99.9 & 1.87 & 301.2 & 202.9 & 504.0 & 2579.3 \\
\hline & 4 & 162 & 50 & 19.1 & 128.0 & 228.2 & 99.1 & 1.78 & 271.1 & 199.0 & 470.1 & 2124.5 \\
\hline & 5 & 163 & 73 & 27.5 & 135.1 & 253.2 & 103.2 & 1.87 & 325.0 & 224.2 & 549.1 & 3350.7 \\
\hline & 6 & 165 & 60 & 22.0 & 136.6 & 248.5 & 103.6 & 1.82 & 314.3 & 238.8 & 553.1 & 3477.2 \\
\hline & 7 & 166 & 66 & 24.0 & 130.1 & 241.8 & 98.9 & 1.86 & 309.7 & 195.4 & 505.1 & 2560.9 \\
\hline & 8 & 170 & 58 & 20.1 & 132.3 & 236.9 & 93.1 & 1.79 & 220.5 & 218.6 & 439.1 & 1773.5 \\
\hline & 9 & 171 & 68 & 23.3 & 137.0 & 235.8 & 94.5 & 1.72 & 289.0 & 198.8 & 487.8 & 2348.2 \\
\hline & 10 & 174 & 62 & 20.5 & 124.9 & 237.9 & 106.3 & 1.91 & 292.9 & 217.1 & 510.0 & 2717.1 \\
\hline & 11 & 177 & 64 & 20.4 & 130.2 & 256.7 & 104.3 & 1.97 & 295.3 & 248.6 & 543.9 & 3344.6 \\
\hline & 12 & 178 & 66 & 20.8 & 124.4 & 243.5 & 101.5 & 1.96 & 281.9 & 208.3 & 490.3 & 2412.2 \\
\hline & 13 & 178 & 58 & 18.3 & 122.5 & 234.8 & 107.7 & 1.92 & 281.0 & 209.5 & 490.5 & 2418.7 \\
\hline & 14 & 180 & 75 & 23.1 & 132.3 & 253.7 & 101.4 & 1.92 & 333.3 & 220.5 & 553.8 & 3409.2 \\
\hline & & 169 & 62 & 21.7 & 130.5 & 243.0 & 100.8 & 1.86 & 290.9 & 216.3 & 507.3 & 2699.3 \\
\hline & $\pm \mathrm{SD}$ & 8 & 8 & 2.3 & 4.7 & 8.7 & 4.3 & 0.07 & 27.8 & 15.7 & 34.1 & 528.9 \\
\hline
\end{tabular}


the sexual dimorphism. ${ }^{12,13}$ However with respect to ever more reports about ethnically conditioned differences ${ }^{14,10}$ we had to appreciate the fact that the observed subjects were Slovenians.

The measured values are shown in Table 2 and visualised in the graph (Figures 4 and 5). Subjects are arranged from lowest to tallest according to their body heights and separated according to gender. The results of the Pearson correlation and linear multivariate analyses are presented in Tables $\mathbf{3}$ and $\mathbf{4}$.

The fact that the facial size could not be defined in one definite way, led us to find the best approximation. Different parameters were used to describe it: the arithmetic mean of selected landmarks (centroid), ${ }^{2-4}$ those different linear face distances that describe facial height and width, and the relationships between them. ${ }^{15,16}$ There were studies for describing the volume of the head, but mostly measured by CT scans. ${ }^{17,18}$ The CT scans as all other x-ray imaging modalities also give us information about deeper structures, such as bone and so where more obtained data brings advantages over surface scanning modalities. However, x-rays with known radiation risk are of question for study of facial growth and development. The idea of measuring the head volume using anthropometrically assessed landmarks ${ }^{19}$ led us to designing the head-ring. When using it additional data was acquired for determining the head size and for checking the accuracies of standard methods. We obtained head distances that can be presented as head lengths, width and face depth.

The expectation that body height would be in correlation with the head volume was unconfirmed. It most

Table 3: Pearson correlation showing the relationships between the observed parameters

\begin{tabular}{|c|c|c|c|c|c|c|c|c|c|c|}
\hline MALE & Weight & BMI & $\begin{array}{l}\text { Between } \\
\text { ears dist }\end{array}$ & $\begin{array}{l}\text { Crown of } \\
\text { the head } \\
\text { chin dist }\end{array}$ & $\begin{array}{c}\text { Centre } \\
\text { nasion dist }\end{array}$ & $\begin{array}{l}\text { Head } \\
\text { index }\end{array}$ & $\begin{array}{l}\text { Upper } \\
\text { volume }\end{array}$ & $\begin{array}{l}\text { Lower } \\
\text { volume }\end{array}$ & $\begin{array}{l}\text { Whole } \\
\text { volume }\end{array}$ & Ellipsoid \\
\hline Height & $\begin{array}{l}.40 \\
.20\end{array}$ & $\begin{array}{c}-.34 \\
.29\end{array}$ & $\begin{array}{c}-.01 \\
.97\end{array}$ & $\begin{array}{l}.16 \\
.62\end{array}$ & $\begin{array}{l}.05 \\
.87\end{array}$ & $\begin{array}{l}.070 \\
.83\end{array}$ & $\begin{array}{c}-.41 \\
.19\end{array}$ & $\begin{array}{c}-.07 \\
.82\end{array}$ & $\begin{array}{c}-.31 \\
.33\end{array}$ & $\begin{array}{l}.06 \\
.86\end{array}$ \\
\hline Weight & & $\begin{array}{l}.73^{* *} \\
.01 \\
\end{array}$ & $\begin{array}{l}.41 \\
.18 \\
\end{array}$ & $\begin{array}{l}.481 \\
.11 \\
\end{array}$ & $\begin{array}{l}.55 \\
.06 \\
\end{array}$ & $\begin{array}{l}-.221 \\
.49\end{array}$ & $\begin{array}{l}.03 \\
.92 \\
\end{array}$ & $\begin{array}{l}.60^{*} \\
.04\end{array}$ & $\begin{array}{l}.38 \\
.22\end{array}$ & $\begin{array}{l}.00 \\
.69^{*} \\
.01\end{array}$ \\
\hline BMI & & & $\begin{array}{l}.444 \\
.15 \\
\end{array}$ & $\begin{array}{l}.375 \\
.23 \\
\end{array}$ & $\begin{array}{l}.50 \\
.10 \\
\end{array}$ & $\begin{array}{c}-.291 \\
.36 \\
\end{array}$ & $\begin{array}{l}.31 \\
.33 \\
\end{array}$ & $\begin{array}{l}.67^{*} \\
.02\end{array}$ & $\begin{array}{l}.61^{*} \\
.04\end{array}$ & $\begin{array}{l}.65^{*} \\
.02\end{array}$ \\
\hline $\begin{array}{l}\text { Between } \\
\text { ears dist }\end{array}$ & & & & $\begin{array}{c}.234 \\
.47\end{array}$ & $\begin{array}{l}.21 \\
.52\end{array}$ & $\begin{array}{c}-.916^{* * *} \\
.00\end{array}$ & $\begin{array}{l}.32 \\
.31 \\
\end{array}$ & $\begin{array}{l}.72^{* * *} \\
.01\end{array}$ & $\begin{array}{l}.65^{*} \\
.02\end{array}$ & $\begin{array}{l}.72^{* *} \\
.01\end{array}$ \\
\hline $\begin{array}{l}\text { Crown - } \\
\text { chin dist }\end{array}$ & & & & & $\begin{array}{l}.10 \\
.75 \\
\end{array}$ & $\begin{array}{l}.18 \\
.58 \\
\end{array}$ & $\begin{array}{l}.25 \\
.44 \\
\end{array}$ & $\begin{array}{l}.21 \\
.51 \\
\end{array}$ & $\begin{array}{l}.39 \\
.36 \\
\end{array}$ & $\begin{array}{l}.43 \\
.16 \\
\end{array}$ \\
\hline \begin{tabular}{|c|} 
Centre \\
nasion dist.
\end{tabular} & & & & & & $\begin{array}{c}-.18 \\
.61\end{array}$ & $\begin{array}{l}.36 \\
.25\end{array}$ & $\begin{array}{l}.63^{*} \\
.03\end{array}$ & $\begin{array}{l}.62^{*} \\
.03\end{array}$ & $\begin{array}{l}.79^{* * *} \\
.00\end{array}$ \\
\hline Head index & & & & & & & $\begin{array}{l}-.22 \\
.49 \\
\end{array}$ & $\begin{array}{c}-.64^{*} \\
.02 \\
\end{array}$ & $\begin{array}{c}-.54 \\
.07 \\
\end{array}$ & $\begin{array}{c}-.55 \\
.06 \\
\end{array}$ \\
\hline $\begin{array}{c}\text { Upper vol- } \\
\text { ume }\end{array}$ & & & & & & & & $\begin{array}{l}.25 \\
.43\end{array}$ & $\begin{array}{l}.81^{* *} \\
.00\end{array}$ & $\begin{array}{l}.47 \\
.13\end{array}$ \\
\hline \begin{tabular}{|c|}
$\begin{array}{c}\text { Lower vol- } \\
\text { ume }\end{array}$ \\
\end{tabular} & & & & & & & & & $\begin{array}{l}.78^{* *} \\
.00\end{array}$ & $\begin{array}{l}.85^{* *} \\
.00\end{array}$ \\
\hline \begin{tabular}{|c|}
$\begin{array}{c}\text { Whole vol- } \\
\text { ume }\end{array}$ \\
\end{tabular} & & & & & & & & & & $\begin{array}{l}.82^{* * *} \\
.00\end{array}$ \\
\hline \multicolumn{11}{|l|}{ FEMALE } \\
\hline Height & $\begin{array}{l}.55^{*} \\
.04\end{array}$ & $\begin{array}{l}-.24 \\
.40\end{array}$ & $\begin{array}{c}-.36 \\
.21\end{array}$ & $\begin{array}{l}.16 \\
.58\end{array}$ & $\begin{array}{l}.33 \\
.25\end{array}$ & $\begin{array}{l}.51 \\
.06\end{array}$ & $\begin{array}{l}.10 \\
.74\end{array}$ & $\begin{array}{l}.08 \\
.78\end{array}$ & $\begin{array}{l}.12 \\
.69\end{array}$ & $\begin{array}{l}.12 \\
.68\end{array}$ \\
\hline Weight & & $\begin{array}{l}.67^{* * *} \\
.01\end{array}$ & $\begin{array}{l}.28 \\
.34\end{array}$ & $\begin{array}{l}.56^{*} \\
.04\end{array}$ & $\begin{array}{l}.09 \\
.77\end{array}$ & $\begin{array}{l}.28 \\
.34\end{array}$ & $\begin{array}{l}.59^{*} \\
.03\end{array}$ & $\begin{array}{l}.14 \\
.64\end{array}$ & $\begin{array}{l}.55^{*} \\
.04\end{array}$ & $\begin{array}{l}.53 \\
.05\end{array}$ \\
\hline BMI & & & $\begin{array}{l}.63^{*} \\
.02\end{array}$ & $\begin{array}{l}.51 \\
.06\end{array}$ & $\begin{array}{l}-.16 \\
.58\end{array}$ & $\begin{array}{c}-.11 \\
.70 \\
\end{array}$ & $\begin{array}{l}.59^{*} \\
.03\end{array}$ & $\begin{array}{l}.10 \\
.73 \\
\end{array}$ & $\begin{array}{l}.53 \\
.05\end{array}$ & $\begin{array}{l}.51 \\
.07\end{array}$ \\
\hline $\begin{array}{l}\text { Between } \\
\text { ears dist }\end{array}$ & & & & $\begin{array}{l}.45 \\
.11 \\
\end{array}$ & $\begin{array}{l}-.55^{*} \\
.04\end{array}$ & $\begin{array}{l}-.53 \\
.05\end{array}$ & $\begin{array}{l}.29 \\
.31 \\
\end{array}$ & $\begin{array}{l}.28 \\
.34 \\
\end{array}$ & $\begin{array}{l}.36 \\
.20\end{array}$ & $\begin{array}{l}.39 \\
.17\end{array}$ \\
\hline $\begin{array}{l}\text { Crown - } \\
\text { chin dist }\end{array}$ & & & & & $\begin{array}{l}.17 \\
.57 \\
\end{array}$ & $\begin{array}{l}.53 \\
.05 \\
\end{array}$ & $\begin{array}{l}.64^{*} \\
.01\end{array}$ & $\begin{array}{l}.67^{* *} \\
.01\end{array}$ & $\begin{array}{l}.83^{* *} \\
.00\end{array}$ & $\begin{array}{l}.85^{* *} \\
.00\end{array}$ \\
\hline \begin{tabular}{|c|} 
Center - \\
nasion dist.
\end{tabular} & & & & & & $.68^{* *}$ & $\begin{array}{l}.42 \\
.14 \\
\end{array}$ & $\begin{array}{l}.29 \\
.32 \\
\end{array}$ & $\begin{array}{l}.47 \\
.09 \\
\end{array}$ & $\begin{array}{l}.46 \\
.10 \\
\end{array}$ \\
\hline Head index & & & & & & & $\begin{array}{l}.33 \\
.25 \\
\end{array}$ & $\begin{array}{l}.38 \\
.19 \\
\end{array}$ & $\begin{array}{l}.44 \\
.11 \\
\end{array}$ & $\begin{array}{l}.44 \\
.12 \\
\end{array}$ \\
\hline $\begin{array}{c}\text { Upper vol- } \\
\text { ume }\end{array}$ & & & & & & & & $\begin{array}{l}.17 \\
.57\end{array}$ & $\begin{array}{c}.89^{* *} \\
.00\end{array}$ & $\begin{array}{l}.84^{* *} \\
.00\end{array}$ \\
\hline \begin{tabular}{|c|}
$\begin{array}{c}\text { Lower vol- } \\
\text { ume }\end{array}$ \\
\end{tabular} & & & & & & & & & $\begin{array}{l}.59^{*} \\
.03 \\
\end{array}$ & $\begin{array}{l}.67^{* *} \\
.01 \\
\end{array}$ \\
\hline \begin{tabular}{|c|} 
Whole vol- \\
ume
\end{tabular} & & & & & & & & & & $\begin{array}{l}.99^{* *} \\
.00\end{array}$ \\
\hline
\end{tabular}


Table 4: Linear multivariate analysis; the whole volume obtained with the head ring is the dependent value, and the parameters that describe the head in different linear perspectives, body height and width, are the independent variable

\begin{tabular}{|c|c|c|c|c|c|}
\hline \multirow{2}{*}{ MALE } & \multicolumn{2}{|c|}{ Non-standardised coefficients } & \multirow{2}{*}{$\begin{array}{c}\text { Standardised coeffi- } \\
\text { cients } \\
\text { Beta }\end{array}$} & \multirow{2}{*}{$\mathrm{t}$} & \multirow{2}{*}{ Sig. } \\
\hline & $\mathrm{B}$ & Std. Error & & & \\
\hline (Constant) & -813.16 & 694.01 & & -1.17 & 0.29 \\
\hline Height & -1.91 & 1.23 & -0.32 & -1.55 & 0.17 \\
\hline Weight & -0.681 & 1.50 & -0.13 & -0.45 & 0.67 \\
\hline Between ears dist. & 4.64 & 1.74 & 0.53 & 2.67 & 0.04 \\
\hline Crown - chin dist & 2.38 & 2.22 & 0.22 & 1.07 & 0.32 \\
\hline $\begin{array}{l}\text { Centre - nasion } \\
\text { dist. }\end{array}$ & 5.16 & 2.02 & 0.57 & 2.56 & 0.04 \\
\hline \multicolumn{6}{|l|}{ FEMALE } \\
\hline (Constant) & -815.66 & 255.91 & & -3.19 & 0.01 \\
\hline Height & -0.51 & 0.65 & -0.12 & -0.78 & 0.46 \\
\hline Weight & 0.84 & 0.72 & 0.19 & 1.17 & 0.28 \\
\hline Between ears dist. & 3.10 & 1.33 & 0.42 & 2.33 & 0.05 \\
\hline Crown - chin dist & 1.75 & 0.57 & 0.45 & 3.09 & 0.02 \\
\hline
\end{tabular}

probably only correlate $(p=0.06)$ with the female head index, which meant that taller women usually have narrower faces. The weight alone was less important and was included in the more descriptive BMI. The initial observations showed that BMI had some statistically significant correlation with the head volume in general. Specifically, it correlated with the lower head volumes and ellipsoid sizes in men, while in women there was a highly significant correlation with the upper head volume that effected the whole volume. Whilst BMI in men did not correlate with any linear distance, in women it was significantly connected to facial width and to facial length $(p=0.06)$. Any connection to BMI was a surprise because the measured head volume was based on landmarks set on structures with less subcutaneous fat, whilst the greatest impact of higher BMI was in other areas.

In men facial width and depth correlated to lower volumes, which were significantly connected to the head and ellipsoid volumes. The same correlation among the lower volumes, the ellipsoids, and the whole head volumes could be seen in women, but the upper volume had a higher impact on the ellipsoid. Facial length showed correlations to lower, upper, ellipsoid, and whole volumes, while the distances between the ears and those from the centre to the nasion did not show any significant correlation with the volumes. It seems that the head length was the more important parameter during the head size determination for the women, while the head width determined the head sizes in men. All the parameters describing the head volume more frequently correlated with the lower volume for men, but to the whole head's volumes for women. The ellipsoid was in correlation with almost all the volumes in both genders, except for the upper ones in men. These results were expected to some extent as a head's shape can be approximated by an ellipsoid, the volume of which depends on the lengths of all three axes. In the case of the head, the distance between the chin and the crown of the head represents the major axis, and the distance between the ears being one of the minor axes and the doubled distance between the nasion and the centre being the second minor axis.

The linear-regression model used to observe any interrelationships' influences between the head length, width, face depth, body weight and height, and the head-volume confirmed some previously stated connections. In both genders the distances from the centre to the nasion (facial-depth) had the highest impacts on the head volumes. The head-width had a slightly lower influence on the heads' volumes, but both of them were statistically significant. In women, the head length had significantly positive influence on the head volumes, in contrast to men where this relationship was insignificant.

Similar studies could not be found in the literature. No differences in the influences of sizes on facial-shape between genders were reported; ${ }^{12}$ but the study was made on the skulls of known sexes.

There is no data available about volumetric proportions among upper and lower facial parts as in our study, which makes it difficult to compare the results with any other research. The different correlations between upper or lower volumes in women and men were very interesting. In Indians, through linear measurements the ratio of the anterior facial height to the total anterior facial height was found to be non-gender specific ${ }^{20}$ and a similar phenomenon was reported for Sweden. ${ }^{21}$ If there are differences between them and our population they are ethnically conditioned, as it was confirmed that the average Slovenian male and female faces with normocclusion have more developed chin region when compared to the Welsh population. ${ }^{9}$ Gender-specific differences found in the chin region have been described, ${ }^{22,23}$ but they were observed independently of the upper part of the head and face. The described gender-specific differences in the lower volume compared to the upper could also be explained by more masculine faces with pronounced lower parts of the face, which have been evolutionarily more 
often selected for reproduction, as explained in anthropologic studies. ${ }^{24}$

\section{CONCLUSIONS}

The head size parameters are gender-specific in Slovenians. In men the head-width and the lower head volume are the main contributors to the head size, while in women the head length and upper volume determine the women's head sizes. BMI significantly correlates to the whole head and lower head volumes in men, while in women highly significantly influences the upper head volume. The BMI in men does not correlate with any linear distance; however, in women it is closely connected to the facial width.

\section{Ethical approval and consent to participate}

This study was reviewed and approved by the Slovenian National Medical Ethics Committee, Approval No. 166/02/13. Signed, informed consent was obtained from The subjects before entering the study.

\section{Consent for publication}

We acquired subject's written permission for the identifiable images.

\section{Competing interests} terests.

The authors declare that they have no competing in-

\section{Funding}

No source of funding must be declared.

\section{Acknowledgement}

Thanks to George Yeoman for his proofreading and Ivan Verdenik for support regarding statistics.

\section{REFERENCES}

${ }^{1}$ M. Y. Hajeer, A. F. Ayoub, D. T. Millett, M. Bock, J. P. Siebert, Three-dimensional imaging in orthognathic surgery: the clinical application of a new method, Int. J. Adult Orthodon. Orthognath. Surg., 17 (2002) 4, 318-30

${ }^{2}$ R. J. Hennessy, J. P. Moss, Facial growth: separating shape from size, Eur. J. Orthod., 23 (2001) 3, 275-85, doi:10.1093/ejo/23.3.275

${ }^{3}$ C. H. Kau, S. Richmond, Three-dimensional imaging for orthodontics and maxillofacial surgery. 2010, Wiley-Blackwell: Chichester, West Sussex, U.K.; Ames, Iowa

${ }^{4}$ M. J. Ravosa, Effects of brain and facial size on basicranial form in human and primate evolution, J. Hum. Evol., 58 (2010) 5, 424-31, doi:10.1016/j.jhevol.2010.03.001

${ }^{5}$ C. H. Kau, J. Knox, A. I. Zhurov, S. Richmond, Validity and reliablity of a portable 3D optical scannind device for field studies., $7^{\text {th }}$ European Craniofacial Congress, Bologna 2004

${ }^{6}$ M. Rana, N. C. Gellrich, U. Joos, J. Piffko, W. Kater, 3D evaluation of postoperative swelling using two different cooling methods following orthognathic surgery: a randomised observer blind prospective pilot study, Int. J. Oral Maxillofac. Surg., 40 (2011) 7, 690-6, doi:10.1016/j.ijom.2011.02.015

${ }^{7}$ T. J. Verhoeven, C. Coppen, R. Barkhuysen, E. M. Bronkhorst, M. A Merkx, S. J. Berge, T. J. Maal, Three dimensional evaluation of fa- cial asymmetry after mandibular reconstruction: validation of a new method using stereophotogrammetry, Int. J. Oral Maxillofac. Surg., 42 (2013) 1, 19-25, doi:10.1016/j.ijom.2012.05.036

${ }^{8}$ M. Bozic, C. H. Kau, S. Richmond, M. Ovsenik, N. I. Hren, Novel method of 3-dimensional soft-tissue analysis for Class III patients, Am. J. Orthod. Dentofacial Orthop., 138 (2010) 6, 758-69, doi:10.1016/j.ajodo.2009.01.033

${ }^{9}$ M. Bozic, C. H. Kau, S. Richmond, N. I. Hren, A. Zhurov, M. Udovic, S. Melink, M. Ovsenik, Facial morphology of Slovenian and Welsh white populations using 3-dimensional imaging, Angle Orthod., 79 (2009) 4, 640-5

${ }^{10}$ L. G. Farkas, M. J. Katic, C. R. Forrest, K. W. Alt, I. Bagic, G. Baltadjiev, E. Cunha, M. Cvicelova, S. Davies, I. Erasmus, R. Gillett-Netting, K. Hajnis, A. Kemkes-Grottenthaler, I. Khomyakova, A. Kumi, J. S. Kgamphe, N. Kayo-daigo, T. Le, A. Malinowski, M. Negasheva, S. Manolis, M. Ogeturk, R. Parvizrad, F. Rosing, P. Sahu, C. Sforza, S. Sivkov, N. Sultanova, T. Tomazo-Ravnik, G. Toth, A. Uzun, E. Yahia, International anthropometric study of facial morphology in various ethnic groups/races, J. Craniofac. Surg., 16 (2005) 4, 615-46

${ }^{11}$ S. Ettl, O. Arold, Z. Yang, G. Hausler, Flying triangulation-an optical 3D sensor for the motion-robust acquisition of complex objects, Applied Optics, 51 (2011) 2, 281-9

${ }^{12}$ A. Rosas, M. Bastir, Thin-plate spline analysis of allometry and sexual dimorphism in the human craniofacial complex, Am. J. Phys. Anthropol., 117 (2002) 3, 236-45, doi:10.1002/ajpa.10023

${ }^{13}$ J. C. Wells, Sexual dimorphism of body composition, Best Pract. Res. Clin. Endocrinol. Metab., 21 (2007) 3, 415-30, doi:10.1016/ j.beem.2007.04.007

${ }^{14}$ F. Fang, P. J. Clapham, K. C. Chung, A systematic review of interethnic variability in facial dimensions, Plast. Reconstr. Surg., 127 (2011) 2, 874-81, doi:10.1097/PRS.0b013e318200afdb

${ }^{15}$ S. E. Bishara, G. J. Jorgensen, J. R. Jakobsen, Changes in facial dimensions assessed from lateral and frontal photographs. Part I-Methodology, Am. J. Orthod. Dentofacial Orthop., 108 (1995) 4, 389-93

${ }^{16}$ L. G. Farkas, J. C. Posnick, T. M. Hreczko, Anthropometric growth study of the head, Cleft Palate Craniofac. J., 29 (1992) 4, 303-8

${ }^{17}$ F. J. Hahn, W. K. Chu, J. Y. Cheung, CT measurements of cranial growth: normal subjects, AJR Am. J. Roentgenol., 142 (1984) 6, 1253-5, doi:10.2214/ajr.142.6.1253

${ }^{18}$ E. Wikberg, P. Bernhardt, G. Maltese, P. Tarnow, J. H. Lagerlof, L. Kolby, A new computer tool for systematic evaluation of intracranial volume and its capacity to evaluate the result of the operation for metopic synostosis, J. Plast. Surg. Hand Surg., 46 (2012) 6, 393-8, doi:10.3109/2000656X.2012.718716

${ }^{19}$ M. J. Baer, Dimensional changes in the human head and face in the third decade of life, Am. J. Phys. Anthropol., 14 (1956) 4, 557-75

${ }^{20}$ O. P. Kharbanda, S. S. Sidhu, K. R. Sundrum, Vertical proportions of face: a cephalometric study, Int. J. Orthod., 29 (1991) 3-4, 6-8

${ }^{21}$ A. Björk, The Face in Profile: An Anthropological X-ray Investigation on Swedish Children and Conscripts. 1972, Odontologisk Boghandels Forlag

${ }^{22}$ M. M. Chakravarty, R. Aleong, G. Leonard, M. Perron, G. B. Pike, L. Richer, S. Veillette, Z. Pausova, T. Paus, Automated analysis of craniofacial morphology using magnetic resonance images, PLoS One, 6 (2011) 5, e20241, doi:10.1371/journal.pone.0020241

${ }^{23}$ R. J. Hennessy, S. McLearie, A. Kinsella, J. L. Waddington, Facial surface analysis by 3D laser scanning and geometric morphometrics in relation to sexual dimorphism in cerebral-craniofacial morphogenesis and cognitive function, J. Anat., 207 (2005) 3, 283-95, doi:10.1111/j.1469-7580.2005.00444.x

${ }^{24}$ Z. M. Thayer, S. D. Dobson, Sexual dimorphism in chin shape: implications for adaptive hypotheses, Am. J. Phys. Anthropol., 143 (2010) 3, 417-25, doi:10.1002/ajpa.21330 